\title{
EQUILIBRIUM
}

Quarterly Journal of Economics and Economic Policy

VOLUME 7 ISSUE 3, 2012

ISSN 1689-765X

Joanna Rydarowska-Kurzbauer *

Silesian University of Technology, Poland

\section{Gdp Fluctuation and Changes in Consumption AND InVESTMENT. CoMPaRATIVE Analysis of Polish Economy and Some Countries of THE EUROPEAN UNION}

JEL Classification Codes: E21, E22, E32

Keywords: dynamics of change in GDP, consumption, investment, similarity of changes in the dynamics of production and global demand in selected EU Countries

\begin{abstract}
The turn of the century was full of dynamic and multi-dimensional changes in the global economy. The most spectacular phenomena may include financial crises. They exerted influence not only on the economy, in which they appeared, but as a result of deepening of globalization, spread "infecting" others. The purpose of this article was an attempt to find similarities in the dynamics of changes in production and global demand that characterized the economy of the selected European Union countries. Information on the selected countries was gathered by analysis of statistical data. The starting point was to show the dynamics of gross domestic product $(G D P)$ in selected countries and to find similarities between them. In the next section, attention was focused on the changes in the two components of aggregate demand: consumption and investment, particularly on their correlation with the rate of change of GDP. For analysis the economy of the European Union (repre-

(C) Copyright Nicolaus Copernicus University Press

Date of Submission: March 1, 2011; date of acceptance: March 19, 2012

* Contact: e-mail: jrk@kurzbauer.pl, Politechnika Śląska, WOIZ, ROZ5, ul. Roosevelta 26-28, 41-800 Zabrze, Poland
\end{abstract}


sented by the euro zone) and the economy of Central and Eastern Europe were selected.

\section{INTRODUCTION}

Both the nineties of the twentieth century and the first decade of the new century are undoubtedly difficult times for many economies in the world. During this period, the Polish economy and the economies of the other countries of Central and Eastern Europe developed in terms of important economical and political transformations, such as: transition, the integration of European countries and globalization. These processes have led to the emergence of new opportunities in markets, states and businesses. New challenges, opportunities but also threats for those who are unable to respond to those challenges, have appeared. The transition of the system, which means introducing the market mechanism, private ownership and democracy, formed the basis for creating new businesses opportunities. The implemented economic reforms were also determined by two processes: globalization and integration. The relationship of both phenomena is not being specified for now. Some authors believe that these are very similar phenomena. Some of them say that integration facilitates the process of globalization. Some other sustain that integration is a part of globalization. In the literature on the subject, the belief that integration is a specific response to globalization persists.(Kosiedowski 2004, p. 164). Nevertheless, the definition of globalization of the world economy has many similarities to the definition of the concept of integration. Both phenomena can be described as merging of economic activity on an international scale by removing barriers to the movement of goods, services and factors of production. In addition, both the globalization and integration are creating new forms of trade, production, financial, scientific and technical links. The reasons for both processes are similar: increase in the trade area, concentration of production, increase in the series of produced goods and reducing unit costs, increase in investment, technological progress, easier access to the factors of production, etc. The difference between these concepts boils down to the fact that integration means rather merging groups of countries, while the globalization of national economies makes them combine in the world as a whole. In the related literature, globalization is presented as an interdisciplinary phenomenon involving the economy, political aspects, culture and technology. In economic meaning the concept of globalization is the process of creating a single market for goods, services and factors of production, covering all countries and geographic regions. (Bożyk, Misala 2003, p. 239). This leads to the growth of economic links between national and international markets, which com- 
bine into one whole. Globalization also means unlimited access to domestic and foreign markets for all business entities, regardless of the country and geographical region. In this perspective, this concept can be understood as a process of progressive internationalization of production, distribution, marketing and exchange of goods, services, capital, labor, technology and natural resources (Bożyk, Misala 2003, p. 240). Both processes - globalization and integration - also exposes economies on some inconvenience. Although they do not exclude the diversity of national models of economic systems, but this uniformity, which is demand for integration, can interfere with maintaining economic sovereignty. Therefore, the ongoing process of globalization requires consideration of two types of mechanisms. Namely: the first one, the business fluctuations between countries and the second one, the emergence of the homogeneous world economy capable for generating economic fluctuations (Wojtyna 2009, p. 252). Hence, there are the question: how many economic problems started in one country, launch a sequence of events involving other countries.

The last "shocks" that appeared in the world economy took place in Asia in 1997, in Russia a year later, in 1999 in Brazil, at the beginning of the twenty-first century in Argentina and Turkey, and now in the United States (U.S.). Financial turmoil of 2007, which appeared in the center of the world economy, the U.S., began to spread to the real U.S. economy, while penetrating into other economies. Hence, it is Europe and most of all its postsocialist countries fear about their future in this globalized world. Therefore, the aim of the article was an attempt to find similarities in the dynamics of changes in production and global demand that characterized the economies of selected European Union (EU) countries. For analysis and comparisons were selected the following economies: the economy of the European Union (represented by the euro area - EA) and the economy of Central and Eastern Europe. The countries - representatives of Central and Eastern Europe, chosen mainly for historical and geographical reasons were: Poland, Czech Republic, Hungary and Slovakia. On the one hand, the geographical situation of these countries was taken into account, on the other hand, their common "integrating" history. On the road to the European integration, they have two common dates: the year 1991 (when they signed the Association Agreement with the European Community) and the year 2004, in which the agreement came into effect. Therefore, the analysis covered the years 2000-2009, including 2004 as a breakthrough for the selected economies. Another characteristic moment for considerations of this article was 2007.

The starting point was the presentation of the dynamics of gross domestic product (GDP) in the selected countries and the attempt to find similarities between them. In the next section attention has been focused on changes in 
global demand of two components: consumption and investment, particularly on their correlation with the rate of change of GDP.

\section{ANALYSIS OF THE DYNAMICS OF CHANGES OF GDP IN THE SELECTED COUNTRIES}

The beginning of the analyzed period is characterized by lower and lower rate of GDP growth. This trend, which lasted in Poland from 1996, remained until 2001. After that time, constant growth in production can be observed in Polish economy . Apart from the one-time decline in 2005, in 2007 it can be seen that the growth rate reached its maximum value and equaled $6.8 \%$. The most characteristic moment in this period is a breakthrough during the years 2008 and 2009, when there was a significant decline in GDP growth from $5.1 \%$ to $1.7 \%$. These data are presented in Table 1 . Similar values were characteristic for the changes in GDP of Czech Republic, but earlier than in Poland. Already in 2008 we can observe a significant decline in economic growth, and in 2009 the rate of growth was already negative and equaled $4.1 \%$. A similar trend was seen in the Slovak economy, but it is worth noting that the dynamics of changes were very spectacular. Especially when seen against the background of all the analyzed countries. After very slight changes that occurred in the 90s, the Slovak economy was characterized, in the first decade of the twenty-first century, by a significant acceleration in GDP growth rates, which in 2007 reached $10.6 \%$. The next two years is a period of economic difficulties and reduction in GDP growth to $-4.7 \%$. A slightly different trend can be seen in the Hungarian economy, where, on the one hand, there was the lowest level of GDP growth among the analyzed countries of Central and Eastern Europe. But on the other hand, the moment of economic slump began in 2004. In 2009, the volume of GDP in the economy fell by $6.7 \%$, which was the worst "result" of all the analyzed countries. All these data are shown in table 1.

Considering the changes in GDP growth of the euro area, similar trends can be observed. However, the growth rate of the euro area in the analyzed period was lower than in other countries. According to the World Bank (World Development Indicators 2010, pp. 226-228), the average annual growth for the euro area did not exceed 2\%, compared with Poland, where it amounted to $4.4 \%$, and respectively $4.6 \%$ in Czech Republic, Slovakia $6.3 \%$ and Hungary $3.6 \%$. 
Table 1. GDP growth in the selected countries in 2000-2009

\begin{tabular}{|c|c|c|c|c|c|c|c|c|c|c|}
\hline \multirow{2}{*}{ Country } & \multicolumn{10}{|c|}{ GDP growth in \% } \\
\cline { 2 - 13 } & $\mathbf{2 0 0 0}$ & $\mathbf{2 0 0 1}$ & $\mathbf{2 0 0 2}$ & $\mathbf{2 0 0 3}$ & $\mathbf{2 0 0 4}$ & $\mathbf{2 0 0 5}$ & $\mathbf{2 0 0 6}$ & $\mathbf{2 0 0 7}$ & $\mathbf{2 0 0 8}$ & $\mathbf{2 0 0 9}$ \\
\hline EA & 3.9 & 1.9 & 0.9 & 0.8 & 3.2 & 1.7 & 3.0 & 2.8 & 0.5 & -4.1 \\
\hline $\begin{array}{c}\text { Czech } \\
\text { Republic }\end{array}$ & 3.6 & 2.5 & 1.9 & 3.6 & 4,5 & 6.3 & 6.8 & 6.1 & 2.5 & -4.1 \\
\hline Hungary & 8.4 & 2.5 & 4.1 & 1.5 & 4,4 & 5.4 & 5.0 & 6,6 & 1.4 & -3.7 \\
\hline Poland & 4.3 & 1.2 & 1.4 & 3.9 & 5,3 & 3.6 & 6.2 & 6,8 & 5.1 & 1.7 \\
\hline Slovakia & 1.4 & 3.5 & 4.6 & 4.8 & 5,0 & 6.7 & 8.5 & 10.6 & 6.2 & -4.7 \\
\hline
\end{tabular}

Source: Eurostat and DG ECFIN (2010, p. 14-15).

To demonstrate the similarity or dissimilarity of the analyzed phenomena, statistical measure of correlation coefficient was chosen. Table 2 shows the correlation coefficients which were calculated to show the dynamics of GDP for all countries.

Table 2. The correlation coefficients

\begin{tabular}{|c|c|c|c|c|}
\hline \multirow{2}{*}{ Lata } & \multicolumn{4}{|c|}{ The correlation coefficients for countries } \\
\cline { 2 - 5 } & EA - Czech & $\begin{array}{c}\text { EA - } \\
\text { Hungary }\end{array}$ & EA- Poland & EA - Slovakia \\
\hline $2000-2004$ & 0.478 & 0.852 & 0.507 & -0.816 \\
\hline $2005-2009$ & 0.989 & 0.937 & 0.889 & 0.977 \\
\hline
\end{tabular}

Source: own study based on Eurostat and DG ECFIN (2010, p. 14-15).

The correlation coefficient can range from -1 to 1 . Positive and negative value of the coefficient indicates the direction of the correlation. The absolute value stands for strength of correlation. Therefore, the sign "minus" means quite the opposite correlation, and the value of "zero" indicates a complete lack of correlation. The higher, closer to 1, level of the correlation coefficient, the stronger the correlation (Stanisz 2007). In this way, the changes in production of Central and Eastern Europe economies were compared with the changes that occurred in the euro area. These coefficients were calculated for two periods: the first covering the years 2000-2004 and the second for the years 2005-2009. 2004 was the year when selected countries joined the European Union. The coefficient allowed to draw the following conclusions. In the first tested period, the Hungarian economy had the closest relationship with the countries of the euro area. The dynamics of changes in the Polish and Czech GDP showed a moderate relationship with the European countries. However, the trend that occurred in the Slovak economy was quite the opposite (it is indicated by a negative sign and high 
absolute value of the correlation coefficient). After Central and East European countries joined the EU structures, the situation changed dramatically. GDP growth of Czech, Hungarian and Slovak (Slovak economy in particular is a very striking example) economies showed a very strong similarity to the growth of euro zone states. It is illustrated by the correlation coefficients, which are equal to almost 1 . When one talked about Polish economy there was no such a strong dependence. The ratio amounts to 0.89 and it stands for moderate similarity to the euro area countries. These observations are also visible on the graph (Figure 1), where the presented curves illustrating the dynamics of GDP in each country.

Figure 1. The Dynamics of changes in GDP in 2000-2009 in selected countries

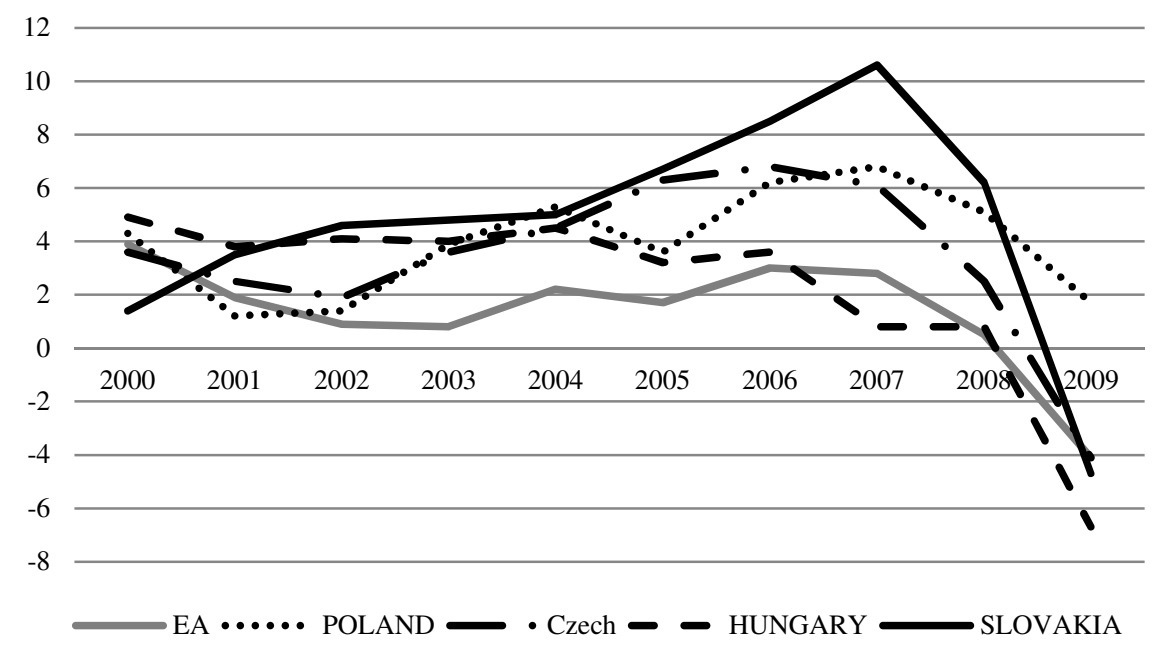

Source: own study based on Eurostat and DG ECFIN (2010, pp. 14-15).

\section{CHANGES IN GDP VERSUS}

CHANGES IN CONSUMPTION AND INVESTMENT

Figures 2 to 6 presents the dynamics of GDP, consumption and investment in the analyzed countries. 
Figure 2. The dynamics of changes in GDP, consumption and investment in 20002009

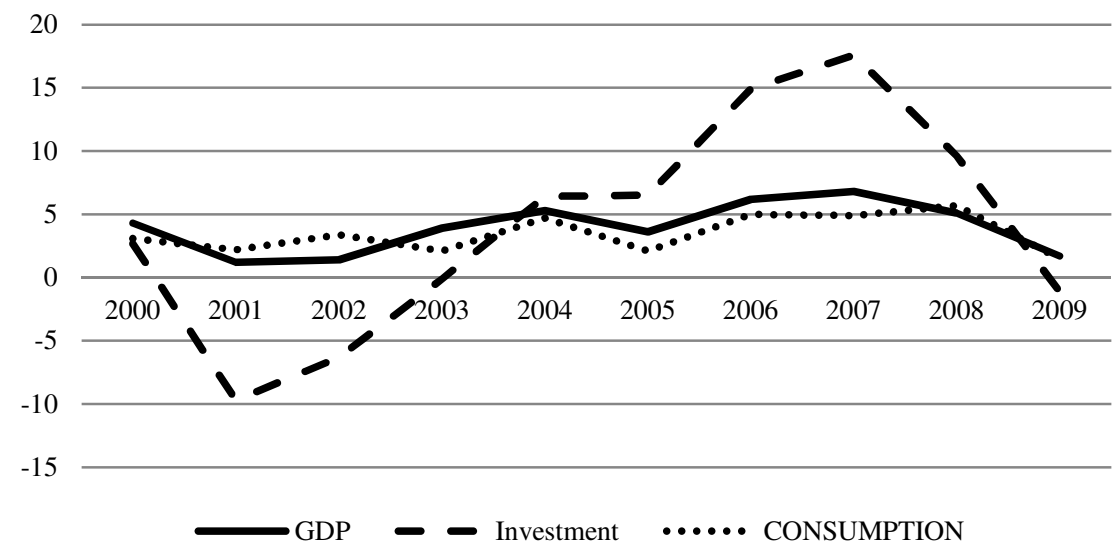

Source: own study based on Eurostat and DG ECFIN (2010, pp. 14-21).

Figure 3. The dynamics of changes in GDP, consumption and investment in 2000 2009 in the Czech Republic

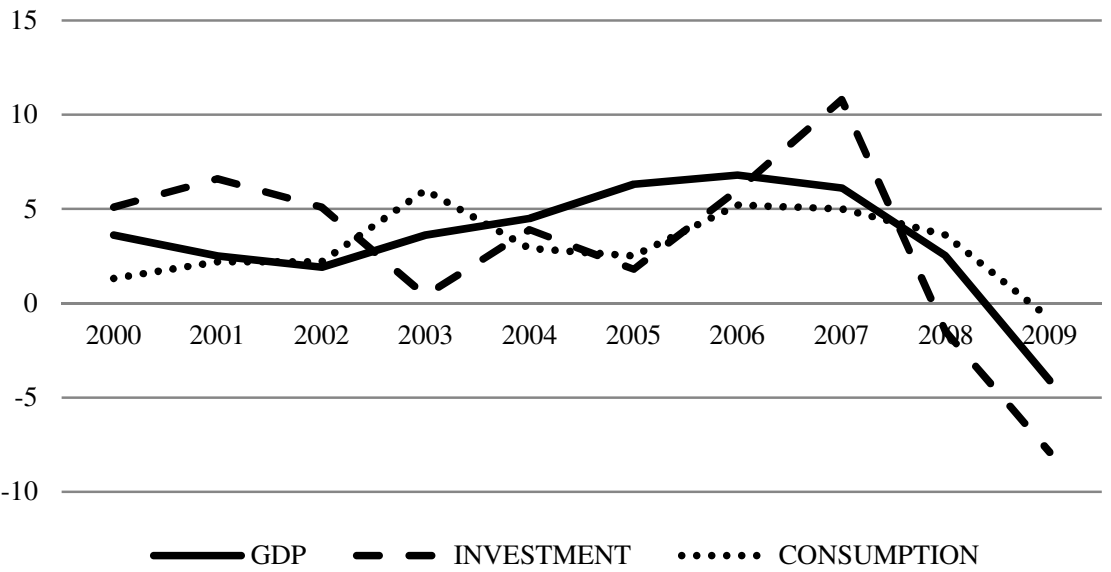

Source: own performance of studies based on Eurostat and DG ECFIN (2010, pp. 14-21). 
Figure 4. The dynamics of changes in GDP, consumption and investment in 20002009 in Hungary

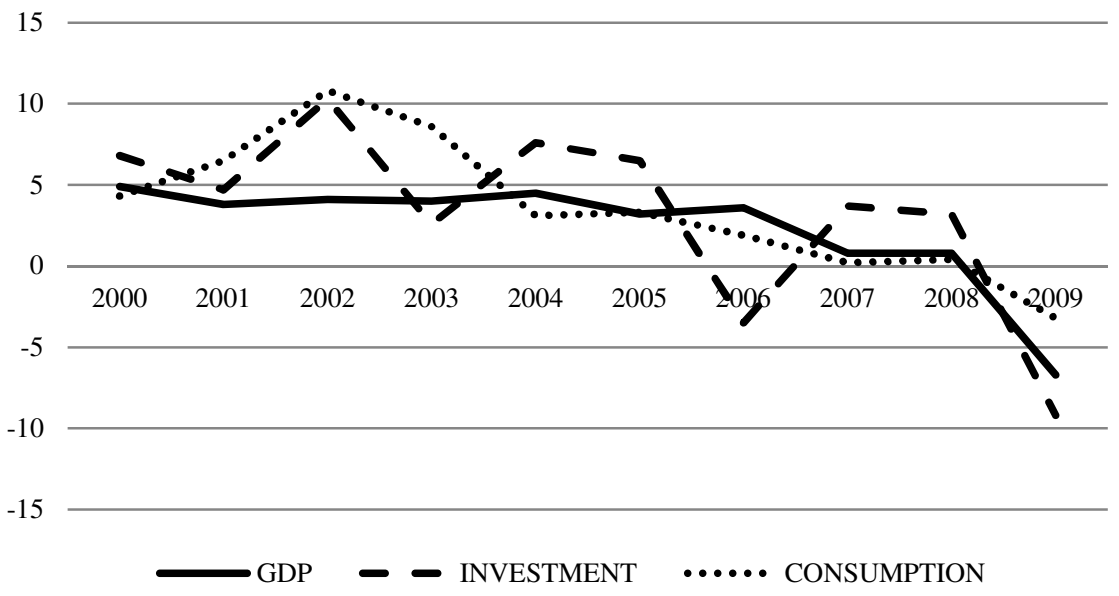

Source: own study based on Eurostat and DG ECFIN (2010, pp. 14-21).

Figure 5. The dynamics of changes In GDP, consumption and investment in 20002009 in Slovakia

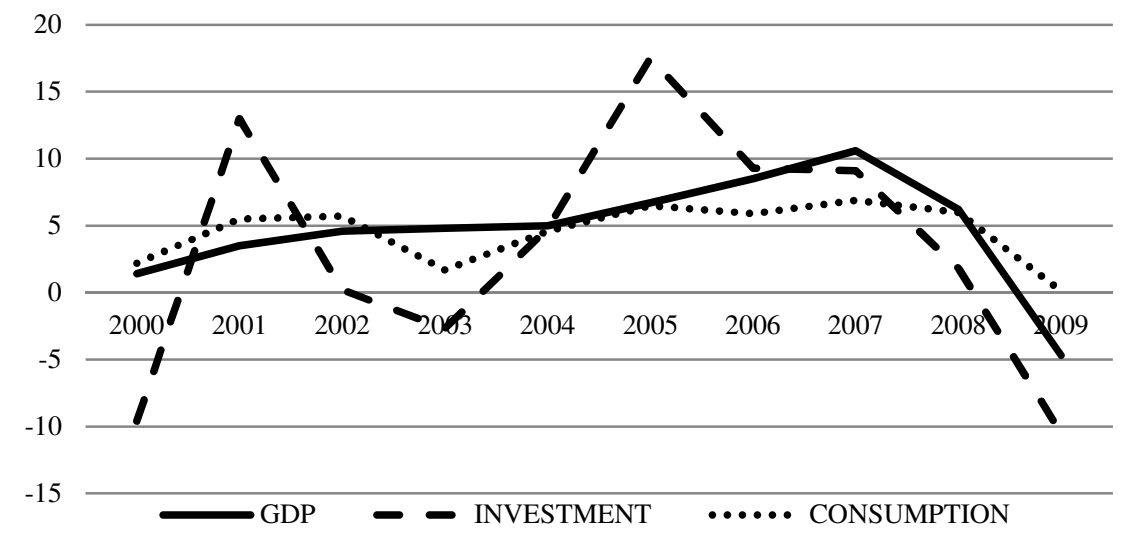

Source: own study based on Eurostat and DG ECFIN (2010, pp. 14-21). 
Figure 6. The dynamics of changes in GDP, consumption and investment in 20002009 in EA

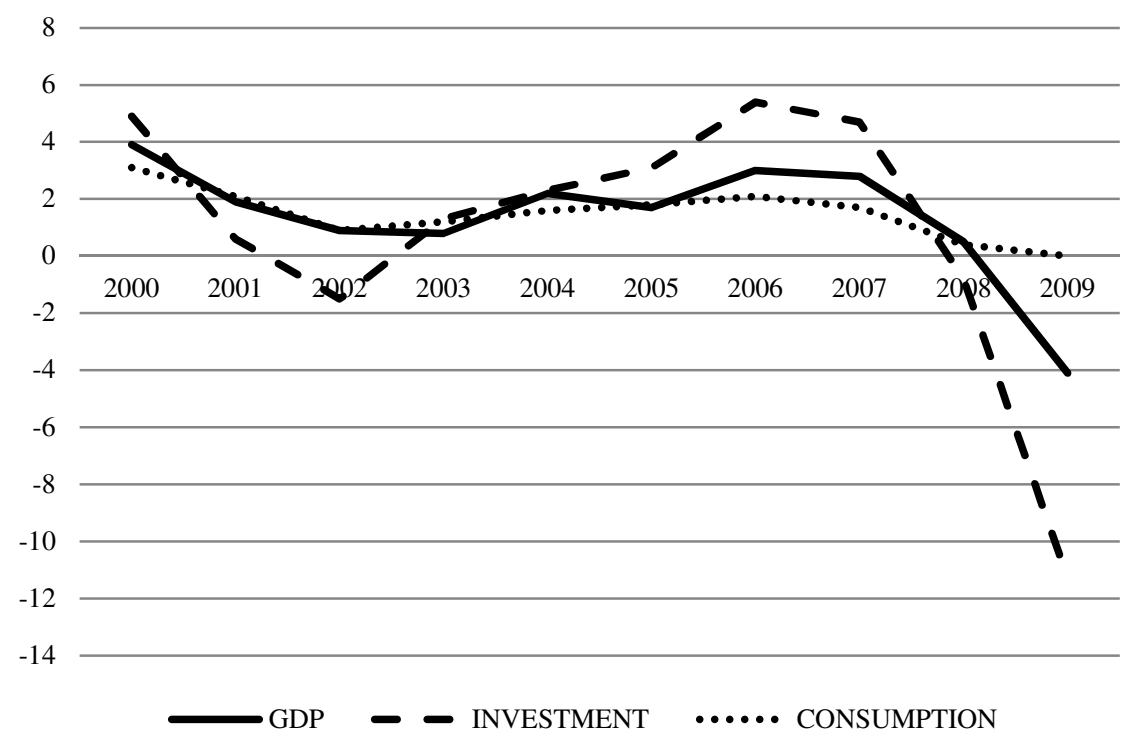

Source: own study based on Eurostat and DG ECFIN (2010, pp. 14-21).

Given the figures above (from Figure 2 to Figure 7), it can be concluded that the most characteristic point on all graphs is the year 2007. This is confirmed by the values of the correlation coefficients calculated for the years 2008-2009, which for all countries amount to 1 . The value of this correlation means full correlation, which occurs when the growth of the value of one variable corresponds to the increase in average values of the other variable. So, in other words, the fluctuations in GDP were accompanied by the same type of fluctuations in consumption and investment. However, in all the analyzed countries the fall in investment growth was much bigger than the decline in consumption growth. And it can be noticed that the rate of decline in consumption was less than the decline in GDP growth. It can be concluded that the decline in GDP was rather due to fluctuations caused by decrease in investment rather than consumption, contrary to what it was like before 2007. This is illustrated in Table 3. 
Table 3. The years 2000-2007

\begin{tabular}{|c|c|c|c|c|c|}
\hline \multirow{2}{*}{ Relation } & \multicolumn{4}{|c|}{ The correlation coefficients for the selected countires } \\
\cline { 2 - 6 } & EA & $\begin{array}{c}\text { Czech } \\
\text { Republic }\end{array}$ & Hungary & Poland & Slovakia \\
\hline $\begin{array}{c}\text { GDP versus } \\
\text { consumption }\end{array}$ & 0.875 & 0.459 & 0.519 & 0.729 & 0.681 \\
\hline $\begin{array}{c}\text { GDP versus } \\
\text { investment }\end{array}$ & 0.836 & 0.157 & 0.258 & 0.955 & 0.568 \\
\hline
\end{tabular}

Source: own study based on Eurostat and DG ECFIN (2010, pp. 14-21).

The correlation coefficients presented in Table 3 indicate the following phenomena. The values, which were characteristic for the Czech, Hungarian, Slovak and euro area economies, were higher in the case of relationships between the dynamics of GDP growth and consumption than in case of the relationship between GDP growth and the dynamics of investment. Such trend, which indicates that the fluctuations in GDP are due to the fluctuations in consumption, is consistent with the IMF report. This report shows that, since the 60s, the overall reduction in GDP values was attributed primarily to fluctuations in consumption, not investment (IMF 2007, chapt. 5). Only the Polish economy was characterized by the fact that the correlation of changes in GDP growth to changes in investment growth was higher than the coefficient relating to consumption. And it is worth noting that in the Polish economy the relationship between the variables analyzed was different. The high value of the euro area economies on both the relationship of GDP - consumption and GDP - the investment may indicate that the fluctuations in GDP affected both investment and consumption. Considering the correlation coefficients for the economies of the Czech Republic, Hungary and Slovakia, you can argue that the dynamics of GDP in these countries are influenced by other, not considered factors.

\section{CONCLUSIONS}

The analysis of GDP growth in the selected countries shows that the most characteristic moment is the year 2007, when all the economies faced a significant slump of production growth. The smallest decrease occurred in Poland. It is worth noting that Poland was the only country in the year 2009 which experienced a positive (although low) economic growth. In the other economies in that year was recorded a negative value for the dynamics of GDP.

Finding similarities between the changes of GDP in the selected countries of Central and Eastern Europe and the countries of EA led to the formulation 
of the following conclusion. Only after the analyzed countries had entered the EU, did the analyzed volumes show a very close similarity. Thus, the thesis that integration has led to the increased penetration of economic phenomena to the new EU economies can be formulated.

The study of the relationship between GDP and the two main components of demand: consumption and investment, leads to the following conclusion. In the period under consideration, there were two characteristic phenomena. The first refers to the years 2000-2007, the second to the subsequent years. The values of correlation coefficients calculated in the first period, were higher for the relationship of GDP - consumption for all economies except Polish. For this country, as the only one, the high ratio for the relationship of GDP - investment was characteristic. In Poland, in 2000-2007, GDP fluctuations resulted primarily from the fluctuations in investment; unlike in other analyzed economies of Central and Eastern Europe, in which changes in GDP were likely to be caused by some other reasons.

It seems reasonable to enrich the analysis by examining the changes in export and import, or collect data from more countries. The correlation coefficient applied in this study is also only one of the statistical measures to detect similarities that characterize the economy.

\section{LITERATURE}

Bożyk P., Misala J. (2003), Integracja ekonomiczna, PWE, Warszawa.

EU economic data pocketbook (2-2010), Eurostat and DG ECFIN.

IMF (2007), Globalization and Inequality, "World Economic Outlook", October.

Kosiedowski W. (2004), Uwarunkowania wzrostu gospodarczego państwa Europy Środkowowschodniej - nowych członków Unii Europejskiej, [in:] Haffer M., Karaszewski W., Czynniki wzrostu gospodarczego, UMK, Torun.

Stanisz A. (2007), Podstawy statystyki dla prowadzacych badania naukowe. Analiza korelacji, http://www.mp.pl/artykuly.

Wojtyna A. (2009) (red), Dostosowania makroekonomiczne i mikroekonomiczne w krajach na średnim poziomie rozwoju po kryzysach finansowych, PWE, Warszawa.

World Development Indicators (2010). 
